\title{
Decontamination Analysis of the NUWAX-83 Accident Site Using "Decon"
}

\section{J. J. Tawil}

November 1983

Prepared for the Defense Nuclear Agency under a Related Services Agreement with the U.S. Department of Energy Contract DE-AC06-76RLO 1830

Pacific Northwest Laboratory Operated for the U.S. Department of Energy by Battelle Memorial Institute 


\section{DISCLAIMER}

This report was prepared as an account of work sponso red by an agency of the United States Government. Neither the United State: Government nor any agency thereof, nor any of their employees, make: arly warranty, express or implied, or assumes any legal liability or responsibi ity for the accuracy, completeness, or usefulness of any information, apparatts, product, or process disclosed, or represents that its use would not infringe privately owned rights. Reference herein to any specific commercial product process, or service by trade name, trademark, manufacturer, or otherwise, does not necessarily constitute or imply its endorsement, recommencation, or favoring by the United States Government or any agency thereof. The views and opinions of authors expressed herein do not necessarily state or ref ect those of the United States Government or any agency thereof.

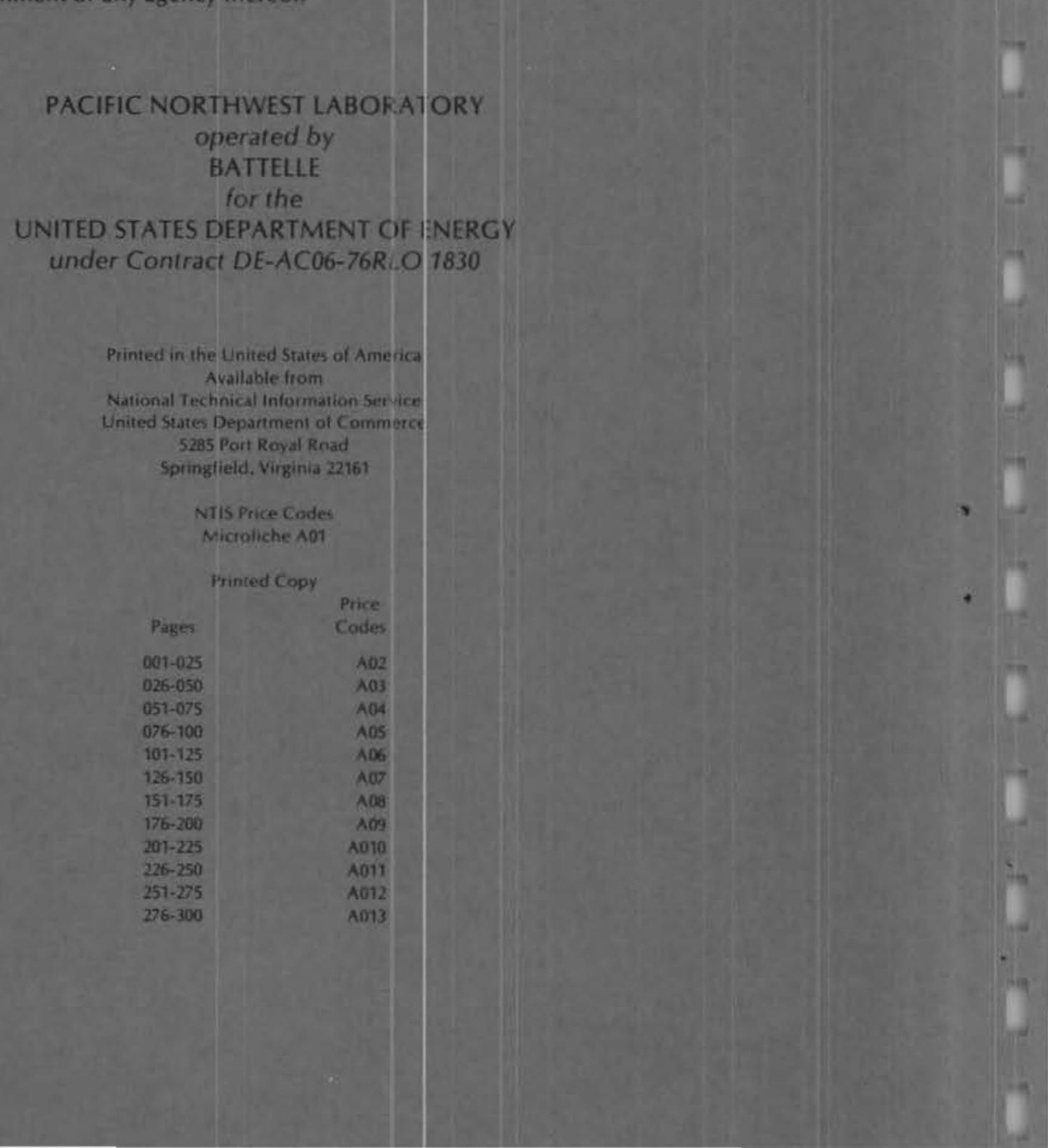


J. J. Tawi1

November 1983

Prepared for the Defense Nuclear Agency under a Related Services Agreement with the U.S. Department of Energy Contract DE-AC06-76RLO 1830

Pacific Northwest Laboratory Richland, Washington 99352 


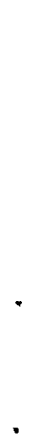




\section{SUMMARY}

This report presents an analysis of the site restoration options for the NUWAX-83 site, at which an exercise was conducted involving a simulated nuclear weapons accident. This analysis was performed using a computer program developed by Pacific Northwest Laboratory. The computer program, called DECON, was designed to assist personnel engaged in the planning of decontamination activities. The many features of DECON that are used in this report demonstrate its potential usefulness as a site restoration planning tool. Strategies that are analyzed with DECON include: 1) employing a QuickVac option, under which selected surfaces are vacuumed before they can be rained on; 2) protecting surfaces against precipitation; 3 ) prohibiting specific operations on selected surfaces; 4) requiring specific methods to be used on selected surfaces; 5) evaluating the trade-off between cleanup standards and decontamination costs; and 6) varying of the cleanup standards according to expected exposure to surface.

The analysis also serves to highlight DECON's flexibility. For example, DECON can analyze virtually any sub-area within the accident site. It can provide summary results for the entire accident site quickly (less than 6 minutes on an IBM PC with floppy disks and under 5 minutes with a hard disk), or it can provide highly detailed results on each grid element.

Other attractive features of DECON which are not been addressed in this report include: 1) the great ease of adding new operations, methods and factor inputs to the reference data base; 2) the relative ease of preparing the site data base; 3 ) the ability of DECON to handle an accident site with a virtually unlimited number of grid elements; 4) the ability to accommodate grid elements of different size, including--via a user-supplied subroutine--sizes that vary according to distance from the accident site, as in a radial gridwork; 5) the ease of introducing site-specific information during run-time, such as rain probability, expected rainfal1, number of days to complete decontamination, and property loss factors related to residual contamination. Finally, DECON has been structured so that additional features and capabilities can be added with minimal changes to the code. 



\section{TABLE OF CONTENTS}

1.0 INTRODUCTION................................................. 1

2.0 A DESCRIPTION OF DECON....................................... 2.1

3.0 DECONTAMINATION ANALYSIS OF THE NUWAX -83 SITE $\ldots \ldots \ldots \ldots \ldots \ldots \ldots \ldots . ., 3.1$

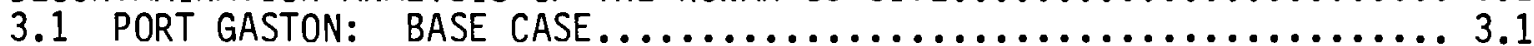

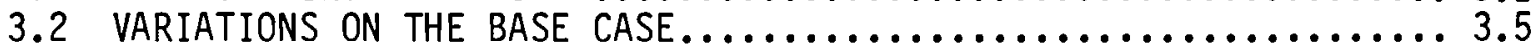

3.2.1 The Quick-Vac Option............................... 3.5

3.2.2 Decontamination Prior to Rain...................... 3.6

3.2.3 Restrictions: Prohibiting the Application of Water...... 3.11

3.2.4 Decontamination Criteria Dependent

Upon Expected Exposures......................... 3.11

3.2.5 The Trade-Off Between Cleanup Standards

And Decontamination Costs........................ 3.14

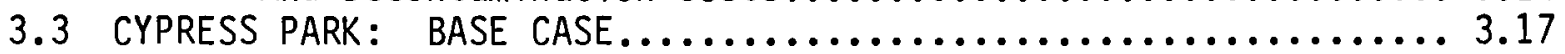

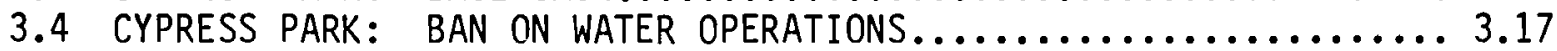

3.5 INDUSTRIAL PARK: BASE CASE............................... 3.17

3.6 INDUSTRIAL PARK: PRE-SPECIFIED DECONTAMINATION METHODS ........ 3.22

3.7 MICRO-ANALYSIS OF THE ACCIDENT SITE....................... 3.22

\section{LIST OF TABLES}

TABLE 1. Decontamination Operations $\ldots \ldots \ldots \ldots \ldots \ldots \ldots \ldots \ldots \ldots \ldots \ldots \ldots .2$

TABLE 2. Land Uses Currently Implemented by DECON................... 2.3

TABLE 3. Surface Types Currentiy Implemented by DECON................ 2.3

TABLE 4. Decontamination Results for the NUWAX Site: Base Case........ 3.2

TABLE 5. Property Loss Factors from Residual Contamination............. 3.4

TABLE 6. Decontamination Results for the NUWAX Site: Quick-Vac Option... 3.7

TABLE 7. Decontamination Results for the NUWAX Site: No Rain........... 3.9

TABLE 8. Decontamination Results for the NUWAX Site: No Water Methods... 3.12

TABLE 9. Decontamination Results for the NUWAX Site:

Varied Exposure Factors.................................. 3.15

TABLE 10. Trade-Off Between Radiation Standards and Decontamination Costs. 3.17

TABLE 11. Decontamination Results for Cypress Park: Base Case.......... 3.18

TABLE 12. Decontamination Results for Cypress Park:

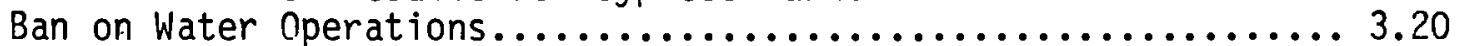

TABLE 13. Decontamination Results for Port Gaston Industrial Park:

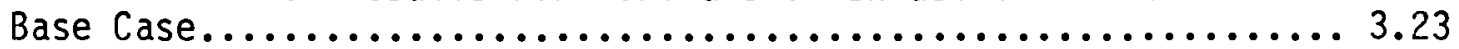

TABLE 14. Decontamination Resuits for Port Gaston Industrial Park:

Pre-Specified Decontamination Methods........................ 3.24

TABLE 15. Micro-Analysis of a Single Grid Element.................... 3.26 


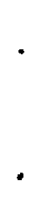




\subsection{INTRODUCTION}

In May 1983, the Department of Defense, Department of Energy, and the Federal Emergency Management Agency jointly sponsored an exercise at the Nevada Test Site (NTS) to test the response of military and civilian agencies to a nuclear weapons accident. Called NUWAX-83, the simulated weapons accident caused an area within a mythical town in Virginia--Port Gaston--to be contaminated by Plutonium and Americium. One objective of the exercise was to determine the procedures necessary to restore the site to unrestricted civilian use. This report presents an analysis to support the decontamination of the NUWAX-83 site.

The decontamination analysis was conducted using a computer program developed by Pacific Northwest Laboratory. The computer program, called DECON, was originally designed for planning decontamination activities following a radiological accident at a nuclear reactor. A specially revised version of DECON was prepared for the Defense Nuclear Agency to be used in planning decontamination activities associated with nuclear weapons accidents. The Defense Nuclear Agency version is described in the following section. 




\subsection{A DESCRIPTION OF DECON}

DECON is a computer program that can provide a large amount of useful information regarding the decontamination of 1 arge 1 and areas. This information includes:

- the least costly decontamination method that is effective

- the cost of the selected decontamination method

- the effectiveness of the selected decontamination method

- the rate at which the selected decontamination method can be applied, and

- the manpower and equipment needed to complete the decontamination.

DECON requires as input two data bases: 1) the reference data base, which consists of information on the various decontamination methods; and 2) the site data base, which contains information about the site to be decontaminated. The reference data base can be applied without alteration to virtually any contaminated site, while the site data base will vary from site to site.

The reference data base consists of a large number of decontamination procedures, their costs, efficiencies and rates of coverage. A list of the decontamination operations currently implemented in DECON and the codes corresponding to these operations are presented in Table 1 . Where more than one operation is given for a code, the correct operation will be apparent from the surface being treated.

In determining what techniques are to be applied to a surface, DECON considers alternative decontamination methods. A decontamination method consists of a combination of one or more decontamination operations. For example, the method VFR consists of the operations: vacuum $(V)$, foam (F), and remove and replace $(R)$. Over 250 decontamination methods are implemented in the current version of DECON.

Additional information on the reference data base is given in (Off-Site Consequences of Radiological Accidents: Methods, Costs and Schedules for Decontamination,, J.J. Tawil et a1., (Draft) March 1983) and in (NUWAX Reference Manual, Preliminary Draft, J.J. Tawil and Bold, F.C., September 1983). 


\section{TABLE 1. Decontamination Operations}

\begin{tabular}{llll} 
Code & \multicolumn{1}{c}{ Operation } & Code & Operation \\
\hline V & Vacuum & F & Foam \\
W & Low Pressure Water & K & Resurface; Repaint Autos \\
H & High Pressure Water & T & Surface Sealer/Fixative; Tow Car \\
Q & Very High Pressure Water & C & Strippable Coating \\
U & Hydroblasting & A & Plow \\
t & Fixative, Aerial Application & L & Leaching-FeCl \\
G & Three-Inch Asphalt & E & Leaching-EDTA \\
R & Remove \& Replace; Reupholster & M & Close Mowing \\
S & Sandblasting & P & Thin Asphalt/Concrete Layer \\
Y Deep Plow & B & Vacuum Blast \\
D & Defoliate; Drive Auto Out & I & Steam Clean \\
N & Clear; Harvest & Z & Renove Structure \\
X Scrape 4"-6" & O & Plane, Scarify; (Radica 1) Prune \\
X Double Scrape & V & Double Vacuum \\
J Wash and Scrub & Z & Renove Interior and Clean \\
m Auto Transport Truck & &
\end{tabular}

The site data base consists entirely of site-specific information, including the type of property (land use) that is on the site, the value of the property, and how severely the property is contaminated. The first step in preparing the site data base is to divide the accident site into a gridwork. In general, the grid element size will depend prinarily on the distance between data points from the radiological survey of the ascident site. A fine grid will likely give more accurate results, but it will also require the user to provide a larger amount of site-specific information.

The grid for the NUWAX site is shown on the map in Figure 1. Each grid element is of size $50^{\prime} \times 50^{\prime}$. The extent to which each grid element has been contaminated is indicated by the contours of ground concentrations of Plutonium 239. Activity levels of $\mathrm{PU}^{239}$ range from less than $0.1 \mu \mathrm{Ci} / \mathrm{m}^{2}$ to over $100 \mu \mathrm{Ci} / \mathrm{m}^{2}$. The activity level of Plutonium 239 is assumed to be 90 percent of the total activity, with Americium 241 making up the remaining 10 percent. Finally, a variety of land uses can be identified on the map, including those listed in Table 2.

An intuitively appealing way of approaching the decontamination problem is to consider the treatment of surfaces. This apprisach is based on the plausibility of using identical methods to decontaminate similar surfaces that are equally contaminated. Some land uses--e.g., streets, wooded areas and vacant land--can each be thought of as consisting of a single type of surface. other land use categories--notably residential, commercial and industrial--are 
TABLE 2. Land Uses Currently Implemented by DECON
1. Residential
2. Commercial
3. Industrial
4. Streets and Roads
5. Wooded Areas
6. Parking Lots
7. Grain Crops
8. Vegetable Crops
9. Orchards
10. Vacant Land

best thought of as consisting of a wide variety of surfaces. Such land uses must be decomposed into their constituent surfaces if they are to be made amenable to the "surface" approach being suggested here. The surface types that are implemented by the current version of DECON are listed in Table 3 below.

TABLE 3. Surface Types Currently Implemented by DECON

1. Agricultural Fields
2. Orchards
3. Vacant Land
4. Wooded Land
5. Exterior Walls, Wood
6. Exterior Walls, Brick
7. Floors, Linoleum
8. Floors, Wood
9. Floors, Carpeted
10. Floors, Concrete
11. Interior Walls, Painted
12. Interior Walls, Concrete

13. Streets and Roads, Asphalt

14. Streets and Roads, Concrete

15. Roofs

16. Lawns

17. (Auto Transport)*

18. Auto Exteriors

19. Auto Interiors

20. Auto Tires

21. Auto Engine and Drive Train

22. Not Used

23. Other Paved Surfaces, Asphalt

24. Other Paved Surfaces, Concrete

*Auto transport is not a surface type; it is included because transporting automobiles to decontamination facilities outside of the contaminated area is a necessary step in the decontamination process.

In addition to ground concentration levels and land use information, DECON also makes use of information on property values. DECON compares the value of a property relative to the cost of decontaminating the property. If the decontamination costs exceed the property value, DECON notes that a buy-out and condemnation of the property may be the most attractive alternative.

DECON also permits the user to enter a set of factors--one for each land use--that expresses the fraction of the original property value lost as a result of the accident. The loss in value is the difference between the pre- 
accident property value and the value of the property after decontamination has been completed; it is attributed to public perceptions of the health risks associated with the residual contamination. These property losses together with the decontamination costs give a partial estimate of the total accident costs. Other costs not included in the estimate are the costs for surveying, monitoring, medical care, loss of employment, evc.cuation, and security.

The ground concentrations, the percent distribution of land use categories and property values are supplied for each grid element. This information comprises the site data base. In the next secticn, DECON is applied to the NUWAX-83 site to demonstrate how it can be used in decontamination planning activities. 


\subsection{DECONTAMINATION ANALYSIS OF THE NUWAX-83 ACCIDENT SITE}

Results on various aspects of the decontamination of Port Gaston, using DECON, are described in this section. First, DECON was run for the entire contaminated area in and around Port Gaston. This run represents the "most likely" scenario, or base case, and is reported in Section 3.1. A variety of different assumptions was then made and the results compared with those from the base case. These are reported in Section 3.2. In Section 3.3 a base case is generated for the residential development Cypress Park. Then the decontamination of Cypress Park is restricted through a ban on the use of operations that use water on exterior surfaces. The results of this scenario are presented in Section 3.4. In Section 3.5 results for a base case scenario for the Port Gaston Industrial Park are presented. These are compared in Section 3.6 with results for the Industrial Park with specific methods being required for certain surfaces. Finally, the last section provides a detailed decontamination analysis for a single grid element.

\subsection{PORT GASTON: BASE CASE}

For the base case it is assumed that it will be at least 60 days before decontamination can be completed. Thus, the likelihood that precipitation will fall on exterior surfaces prior to this is virtually a certainty. It is also assumed that as a result of decontamination, maximum dose to the lung and bones will not exceed 1.0 and $3.0 \mathrm{millirads}$ per year, respectively. The major results of this run are summarized in Table 4, panel (a). Total costs to decontaminate 391,979 square meters of surface area are $\$ 2,119,086$, for an average cost of $\$ 5.41$ per square meter.

Although DECON contains well over 250 decontamination methods at present, 12,272 square meters of surface still could not be adequately decontaminated. The main problem here is that the effect of precipitation on asphalt and concrete surfaces reduces the decontamination efficiencies to the point where even removal and replacement of the surface is inadequate.* One way to solve

*The removal efficiencies used by DECON are based on the contamination originally falling on a surface, even if some of the contaminants subsequently move to another surface. Thus, runoff from rain on paved surfaces will carry contaminants to other surfaces where they will not be removed by removal of the paved surface. However, some of the contamination will be removed when the other surfaces are treated. The removal efficiency estimate is based on a 
TABLE 4. Decontamination Results for the NUWAX Site:

Base Case

(a) SUMMARY RESULTS FOR EXPOSURE AREA 1 TO EXPOSURE AREA 6

TOTAL DECONTAMINATION COSTS ARE ..........

TOTAL AREA DECONTAMINATED IS $\ldots \ldots \ldots \ldots$

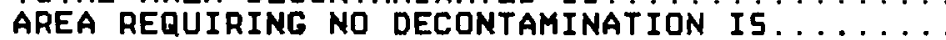
AREA THAT COULD NOT BE DECONTAMINATED IS ..... PRE-ACCIDENT PROPERTY VALUE IS ........... POST-DECONTAMINATION PROPERTY VALUE IS ..... TOTAL REDUCTION IN PROPERTY UALUE IS ........

(b) TOTAL FACTOR INPUT REQUIREMENTS (MAN/EQUIPMENT HOUAS)

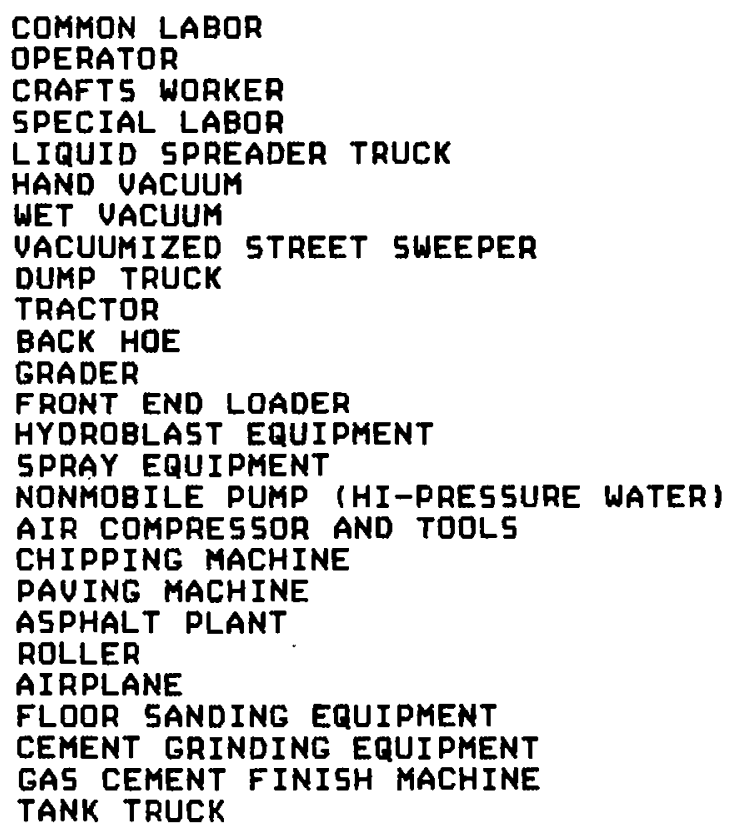

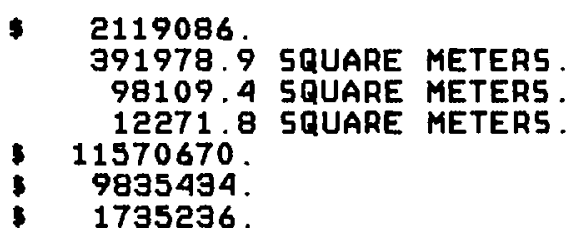


TABLE 4. (Continued)

(c) TOTAL AREA DECONTAMINATED, BY SURFACE AND METHOD

SURFACE TYPE

METHOD

AREA (5Q. METER5)

AGRICULTURAL FIELDS AGRICULTURAL FIELDS

ORCHARD 5

ORCHARDS

VACANT LAND

UACANT LAND

UACANT LAND

VACANT LAND

WOODED LAND

WOODED LAND

EXTERIOR WOOD WALLS

EXTERIOR WOOD WALLS

EXTERIOR WOOD WALL5

EXTERIOR WOOD WALL5

EXTER'R BRICK WALL5

EXTER'R BRICK WALLS

EXTER'R BRICK WALLS

LINOLEUM FLOORS

LINOLEUM FLOORS

LINDLEUM FLOORS

LINOLEUM FLOORS

WOOD FLOORS

WOOD FLOOR5

WOOD FLOOR5

WOOD FLOOR5

WOOD FLOORS

CARPETED FLOORS

CARPETED FLOORS

CARPETED FLOORS

CONCRETE FLOOR5

CONCRETE FLOORS

CONCRETE FLOORS

CONCRETE FLOORS

INT'R WOOD/PL WALLS

INT'R WOOD/PL WALLS

INT'R WOOD/PL WALLS

INT'R WOOD/PL WALLS

INT'R CNCRETE WALLS

INT'R CNCRETE WALLS

INT'R CNCRETE WALLS

INT'R CNCRETE WALLS

ASPHALT STRTS/ROADS

ASPHALT STRTS/ROADS

CNCRETE STRTS/ROADS

CNCRETE STRTS/ROADS

ROOF5

ROOF5

ROOF 5

LAWNS

LAWNS

LAWNS

LAWNS

OTHR PAUED A5PHALT

OTHR PAUED A5PHALT

DTHR PAUED CNCRETE

OTHR PAUED CNCAETE

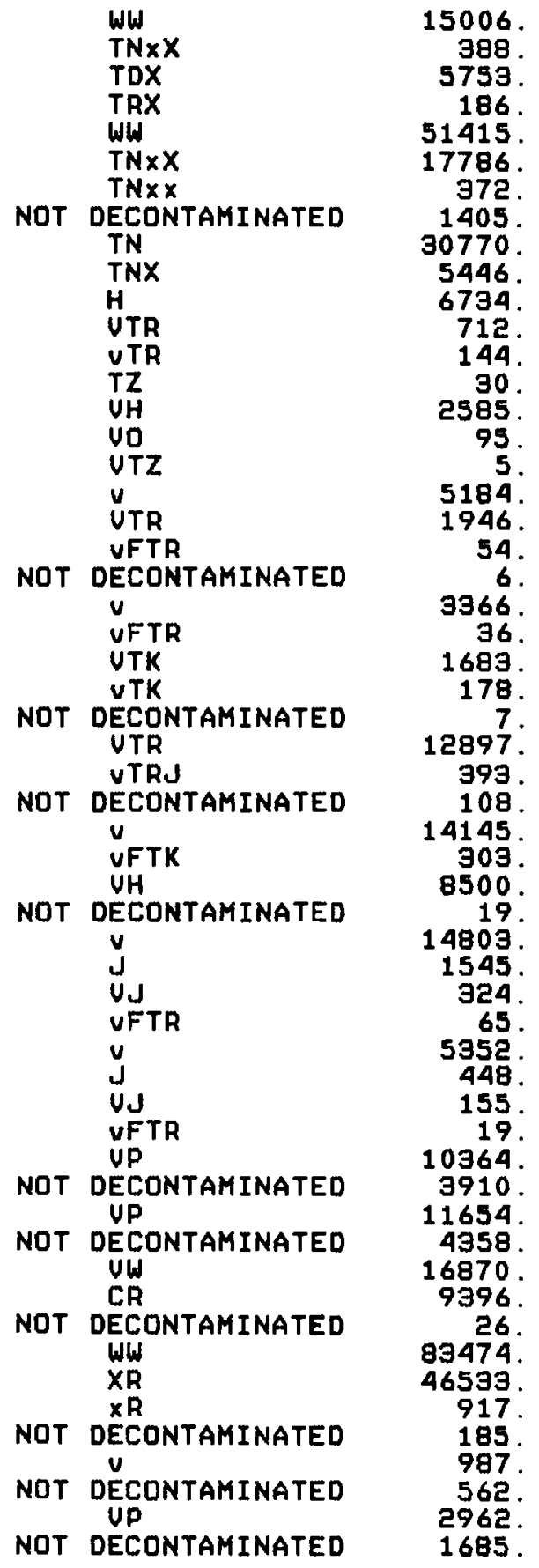


this problem would be to combine removal and replacement with the operation of scraping. Removal and replacement with scraping would cost about $\$ 40$ per square meter.

In addition to the problem with the asphalt and concrete surfaces, most of the surfaces contaminated at levels greater than $100 \mu \mathrm{Ci} / \mathrm{m}^{2}--1,742$ square meters--could not be successfully decontaminated with the methods currently available in DECON. Surfaces that could not be decontaminated are identified in Table 4 panel (c), which lists the areas decontaminated by surface type and method used.

It is expected that a major cost of a weapons accident would be a loss in property values even after decontamination has been completed. These losses result because of the perceived health risks associated with the residual levels of contamination. To demonstrate DECON's capability of estimating this effect, a set of property loss factors has been assumed for the base case. These factors are presented in Table 5.0 and give the fraction of the preaccident property value that has been lost.

\section{TABLE 5. Property Loss Factors from Residual Contamination}

$\begin{array}{llll}\text { Residential } & .20 & \text { Parking Lots } & .05 \\ \text { Commercial } & .10 & \text { Grain Crops } & .25 \\ \text { Industrial } & .10 & \text { Vegetable Crops } & .25 \\ \text { Streets and Roads } & .00 & \text { Orchards } & .25 \\ \text { Wooded Areas } & .05 & \text { Vacant Land } & .10\end{array}$

Because of residual contamination and public jerceptions, we estimated that property value losses in Port Gaston amounted to $\$ 1,735,236$, or an average of 15 percent of the pre-accident property value $(\$ 11,570,670)$. If we add to these property losses the decontamination costs and an estimated $\$ 40$ per square

Footnote Continued... judgment regarding the most likely result after the specified method has been used on the specified surface and other likely methods have been used on other surfaces. While there are some difficulties with this approach, we feel it is far superior to the alternative, which would require keeping track of the contaminants and adding and subtracting them from specific surfaces. For example, in the latter approach, land near the edige of a highway or under a roof would have to be processed by DECON differen"ly from other land; furthermore, the additional information required :o carry out this approach would be substantial. 
meter for surfaces that could not be decontaminated, we arrive at a total damage estimate of $\$ 3.4$ million. This figure excludes costs for monitoring, security, contaminated waste disposal and other items not explicitly included.

Total factor input requirements--i.e., total hours of labor and equipment--are presented in Table 4, panel (b). Where only a few hours of equipment are specified (e.g., vacuumized street sweeper and tank truck) one should consider the practicality of substituting other equipment that is being used more intensively. Also, it is noted that the cost estimates developed for DECON assume that relatively large areas are to be decontaminated with each of the selected methods. Where this is not the case, a cost premium should be added. This is especially true in circumstances where equipment will have to be thoroughly decontaminated before it can be returned to normal service.

\subsection{VARIATIONS ON THE BASE CASE}

In this section we consider five variations on the base case. The first utilizes the Quick-Vac option, under which surfaces are vacuumed before rain or snow can carry the contaminated particles onto other surfaces or into inaccessible areas. The second variation assumes that the decontamination can be completed before precipitation falls on exterior surfaces. In the third variation, a ban is placed on decontamination operations that rely on the use of water on exterior surfaces. The fourth variation considers the effect of decontaminating different surfaces to different standards, depending upon the likely human exposure to the various surfaces. The idea here is to determine whether decontamination costs can be decreased without increasing the expected health risks simply by imposing different cleanup standards on different surfaces. Finally, in the fifth case we demonstrate how DECON can be used to generate trade-off relationships between decontamination costs and cleanup standards.

\subsubsection{The Quick-Vac Option}

The objective of this part of the analysis is to determine whether the Quick-Vac option can produce significant decontamination cost savings. Under this option, exterior surfaces would be vacuumed prior to precipitation, provided it is cost-effective. To exploit this option, state and/or local officials would have to act very quickly to mobilize the necessary manpower and equipment. 
Rerunning DECON under the Quick-Vac option shows that savings of over $\$ 100,000$ could be achieved--total decontamination costs of $\$ 2,017,806$ vs. $\$ 2,119,086$ without Quick-Vac (see Table 6, panel (a)). In addition to these savings, about 1500 square meters of surface that could not be decontaminated under the base case could be cleaned up under this option. Panel (c) indicates that the surfaces likely to benefit from the Quick-Vac option are exterior walls, roofs, streets, roads and other paved surfaces.

It is likely that streets and roads in particular could be given a quick pass with street cleaning equipment. Such equiprent can achieve an effective coverage rate of $8600 \mathrm{sq}$. meters per hour. However, the vacuuming of roofs and exterior walls has an effective coverage rate of only 81 and $69 \mathrm{sq}$. meters per hour, respectively. It is therefore questionable whether much progress could be made on these latter surfaces before it rains or snows, un less large numbers of crews can be quickly mobilized. Finally, we note that DECON selects QuickVac only when it is cost-effective; it does not otherwise make a judgment regarding the feasibility of applying Quick-Vac.

In the case of roofs the potential savings might be sufficiently large so that it would pay to cover them with plastic sheeting, thereby protecting them from rain until they can be treated. This protection should result in removal efficiencies equivalent to those associated with decontamination without prior precipitation.

\subsubsection{Decontamination Prior to Rain}

Generally, precipitation renders most decontanination methods significantly less effective. To measure the effects of precipitation on the decontamination process, DECON was run assuming a 0.0 probability of rain. The results are presented in Table 7 .

Total decontamination costs decline to $\$ 1.8$ million from $\$ 2.1$ million in the base case. Furthermore, the $\$ 1.8$ million includes decontaminating about 10,000 square meters of surfaces that could not be decontaminated under the base case. The remaining 1,937 square meters that still can not be decontaminated are almost entirely in areas receiving over $100 \mathrm{\mu Ci} / \mathrm{m}^{2}$ of $\mathrm{Pu}^{239}$. 
TABLE 6: Decontamination Results for the NUWAX Site: Quick-Vac option

(a) SUMMARY RESULTS FOR EXPOSURE AREA 1 TO EXPOSURE' AREA 6

*** QUICK-UAC OPTION 5ELECTED ****

TOTAL DECONTAMINATION COSTS ARE . . . . . . .

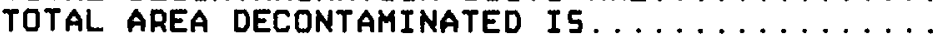

AREA REQUIRING NO DECONTAMINATION IS .......

AREA THAT COULD NOT BE DECONTAMINATED I5 . . .

PRE-ACCIDENT PROPERTY UALUE IS . . . . . .

POST-DECONTAMINATION PROPERTY VALUE IS $\ldots \ldots$

TOTAL REDUCTION IN PROPERTY UALUE IS .......

(b) TOTAL FACTOR INPUT REQUIREMENTS (MAN/EQUIPMENT HOURS)

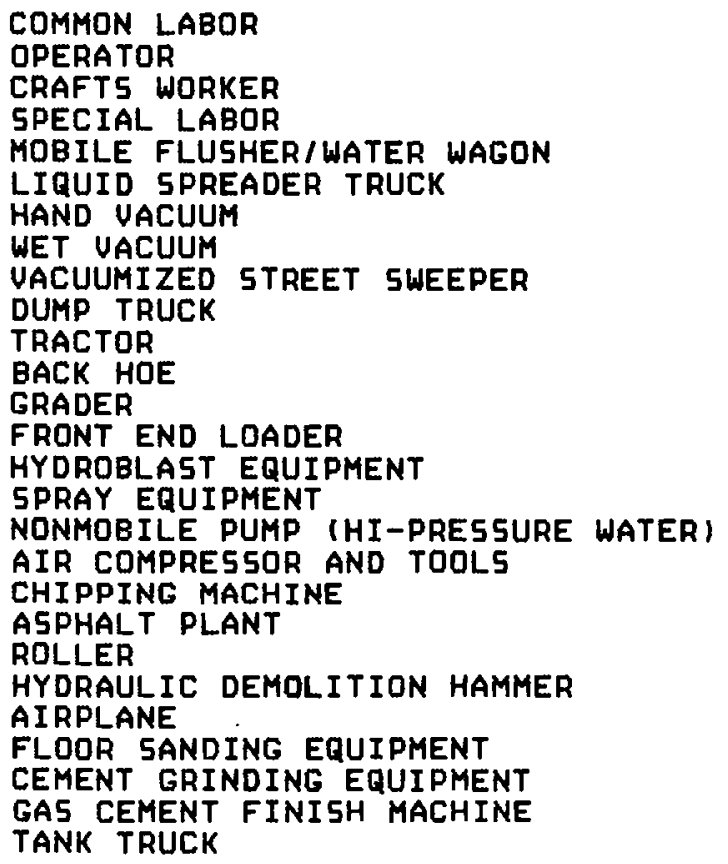

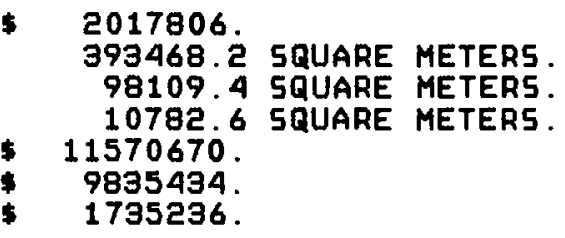


TABLE 6. (Continued)

(c) TOTAL AREA DECONTAMINATED, BY SUIRFACE AND METHOD

SURFACE TYPE

AGRICULTURAL FIELDS

AGR ICULTURAL FIELDS

ORCHARDS

ORCHARD 5

UACANT LAND

UACANT LAND

VACANT LAND

UACANT LAND

WOODED LAND

WOODED LAND

EXTERIOR WOOD WALLS

EXTERIOR WOOD WALLS

EXTERIOR WOOD WALLS

EXTERIOR WOOD WALLS

EXTER'R BRICK WALLS

EXTER'R BRICK WALLS

EXTER'R BRICK WALLS

EXTER'R BRICK WALLS

LINOLEUM FLOORS

LINOLEUM FLOORS

LINOLEUM FLOORS

LINOLEUM FLOORS

HOOD FLOORS

WOOD FLOORS

WOOD FLOORS

WOOD FLOORS

WOOD FLOORS

CARPETED FLOORS

CARPETED FLOORS

CARPETED FLOORS

CONCRETE FLOORS

CONCRETE FLOORS

CONCRETE FLOORS

CONCRETE FLOORS

INT'R WOOD/PL WALLS

INT'R WOOD/PL WALLS

INT'R WOOD/PL WALLS

INT'R WOOD/PL WALLS

INT'R CNCRETE WALLS

INT'R CNCRETE WALLS

INT'R CNCRETE WALLS

INT'R CNCRETE WALLS

ASPHALT 5TRT5/ROADS

ASPHALT STRT5/ROAD5

CNCRETE STRTS/ROADS

CNCRETE STRTS/ROADS

ROOF 5

ROOF 5

ROOF 5

LAWNS

LAWNS

LAWN5

LAWN5

OTHR PAUED ASPHALT

OTHR PAUED ASPHALT

OTHR PAUED CNCRETE

OTHR PAUED CNCRETE

OTHR PAUED CNCRETE
METHOD

AREA (5Q. METERS)

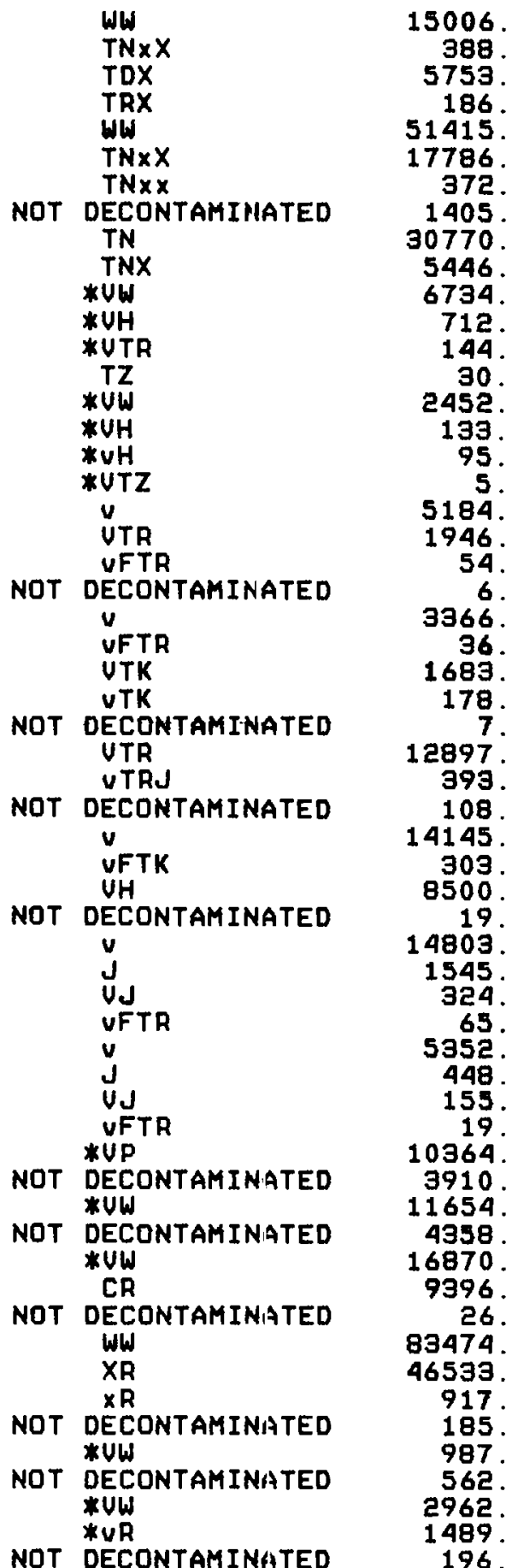

*DENOTES QUICK-VAC OPTION 
TABLE 7. Decontamination Results for the NUWAX Site:

No Rain

(a) SUMMARY RESULTS FOR EXPOSURE AREA 1 TO EXPOSURE AREA 6

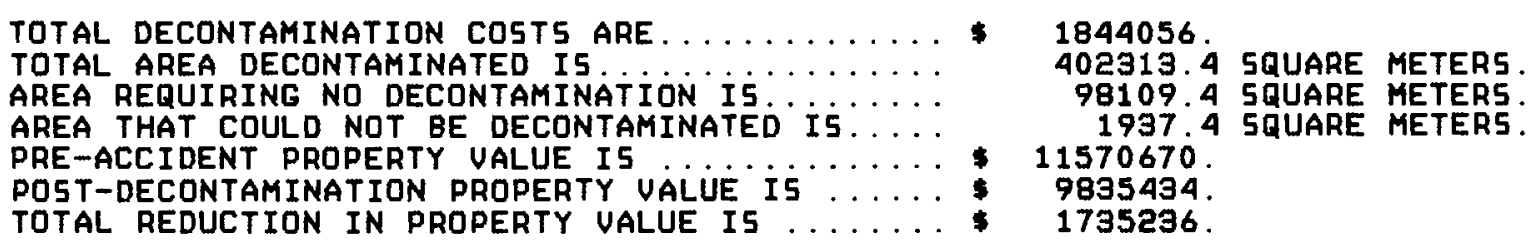

(b) TOTAL FACTOR INPUT REQUIREMENTS (MAN/EQUIPHENT HOUR5)

COMMON LABOR

OPERATOR

CRAFT5 WORKER

5PECIAL LABOR

MOBILE FLUSHER/WATER WAGON

LIQUID 5PREADER TRUCK

HAND VACUUM

WET UACUUM

UACUUMIZED STREET SWEEPER

5PECIAL UACUUM (SUPER SUCKER, ETC.) DUMP TRUCK

TRACTOR

BACK HOE

GRADER

FRONT END LOADER

HYDROBLAST EQUIPMENT

SANDBLAST EQUIPMENT

SPRAY EQUIPMENT

NONMOBILE PUMP (HI-PRES5URE WATER)

AIR COMPRES5OR AND TOOL5

CHIPPING MACHINE

PAUING MACHINE

ASPHALT PLANT

ROLLER

HYDRAULIC DEMOLITION HAMMER

AIRPLANE

FLOOR SANDING EQUIPMENT

CEMENT GRINDING EQUIPMENT

GA5 CEMENT FINISH MACHINE

ROAD PLANER

TANK TRUCK

$$
\begin{array}{r}
14860.26 \\
22668.98 \\
5378.59 \\
5.92 \\
.95 \\
79.79 \\
1474.92 \\
1781.18 \\
2.03 \\
.26 \\
17420.22 \\
130.92 \\
29.66 \\
125.54 \\
411.82 \\
13.44 \\
404.04 \\
240.27 \\
1062.49 \\
18.53 \\
136.15 \\
10.14 \\
12.54 \\
25.65 \\
7.08 \\
3.33 \\
143.14 \\
31.58 \\
60.51 \\
.13 \\
.13
\end{array}
$$


(E) TOTAL AREA DECONTAMINATED, BY SURFACE AND METHOD

SURFACE TYPE

AGRICULTURAL FIELDS AGR ICUL TURAL FIELDS ORCHARD 5

ORCHARD 5

UACANT LAND

VACANT LAND

UACANT LAND

VACANT LAND

WOODED LAND

WOODED LAND

EXTERIOR WOOD WALL5

EXTERIOR WOOD WALLS

EXTERIOR WOOD WALLS

EXTERIOR WOOD WALLS

EXTER'R BRICK WALL5

EXTER'R BRICK WALLS

EXTER'R BRICK WALLS

EXTER'R BRICK WALLS

LINOLEUM FLOORS

LINOLEUM FLOORS

LINOLEUM FLOORS

LINOLEUM FLOORS

WOOD FLOORS

WOOD FLOORS

WOOD FLOORS

WOOD FLOORS

WOOD FLOORS

CARPETED FLOORS

CARPETED FLOORS

CARPETED FLOORS

CONCRETE FLOORS

CONCRETE FLOORS

CONCRETE FLOORS

CONCRETE FLOORS

INT'R WOOD/PL WALLS

INT'R WOOD/PL WALLS

INT'R WOOD/PL WALLS

INT'R WOOD/PL WALLS

INT'R CNCRETE WALLS

INT'R CNCRETE WALLS

INT'R CNCRETE WALLS

INT'R CNCRETE WALLS

ASPHALT STRTS/ROADS

A5PHALT 5TRTS/ROADS

ASPHALT STRTS/ROADS

ASPHALT STRTS/ROADS

ASPHALT STRTS/ROADS

CNCRETE STRTS/ROADS

CNCRETE STRTS/ROADS

CNCRETE STRTS/ROADS

CNCRETE STRTS/ROADS

ROOF 5

ROOF 5

ROOF 5

ROOFS

LAWNS

LAWNS

LAWNS

LAWNS

OTHR PAUED ASPHALT

OTHR PAUED ASPHALT

OTHR PAUED A5PHALT

OTHR PAUED A5PHALT

DTHR PAUED A5PHALT

OTHR PAUED CNCRETE

OTHR PAUED CNCRETE

OTHR PAUED CNCRETE

OTHR PAUED CNCRETE
METHOD AREA (5Q. METERS)

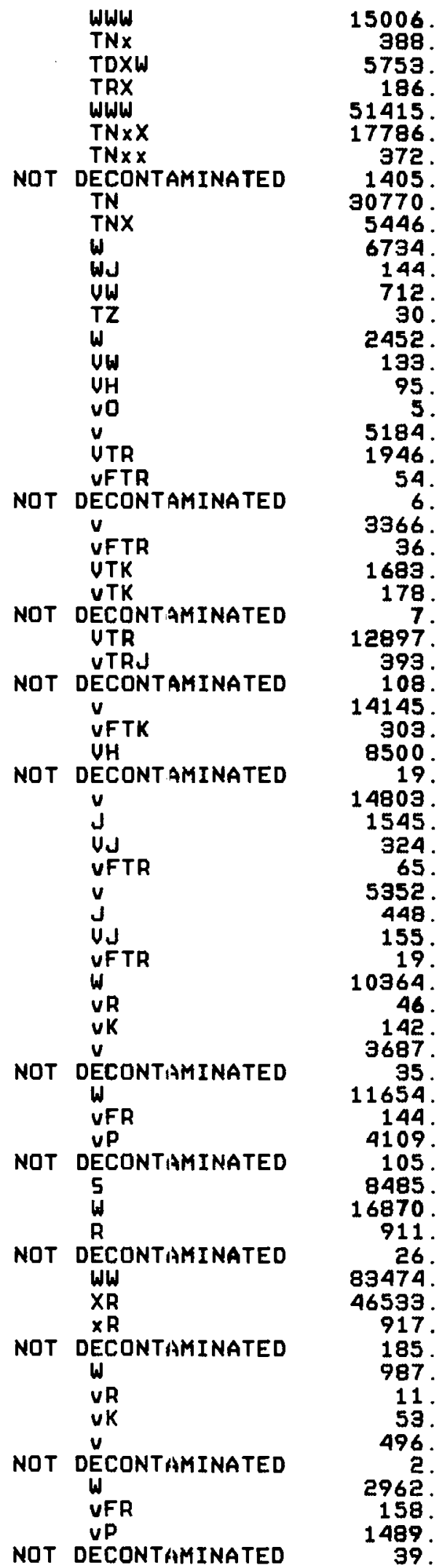




\subsubsection{Restrictions: Prohibiting the Application of Water}

DECON was next applied to determine what the effect would be of prohibiting the use of water while decontaminating exterior surfaces. Contaminated water has the potential of creating major problems. It can penetrate the root systems of plants, crops and trees and contaminate water treatment facilities. The benefits from using water--a cheap and effective way to reduce dosage through the external and inhalation pathways--must therefore be carefully weighed against the costs. The results of running DECON with a ban on operations using water (i.e., operations W, H, Q, U, L and E--see Table 1) are presented in Table 8.

With a ban on the use of water on exterior surfaces, decontamination costs soar to $\$ 3.4$ million. A comparison of Table 4, panel (c) with Table 8, panel (c) reveals which surfaces account for the increased costs. Agricultural fields, vacant land, roofs and lawns all relied to a major extent on water methods for successful decontamination. With the restriction in effect, agricultural fields and vacant 1 and are fixed, cleared and scraped, roofs are sandblasted and lawns are resodded.

\subsubsection{Decontamination Criteria Dependent upon Expected Exposures}

Another application of DECON relates to its ability to allow cleanup standards to be adjusted according to the type of surface. The potential usefulness of this feature lies in the fact that human exposure rates to different surfaces varies considerably. Housing interiors, for example, would usually give high exposure rates while highways and wooded areas would tend to offer low exposure rates. The exposure factors are defined as being inversely proportional to the target decontamination factors, and with values in the base case equal to 1.0. Thus, an exposure factor of 2.0 means that the target decontamination factor for the surface will be just half of what it would be with an exposure factor of 1.0. To illustrate this feature, DECON was run with the following exposure factor values: 
TABLE 8. Decontamination Results for the NUWAX Site:

No Water Methods

(a) SUMMARY RESULTS FOR EXPOSURE AREA 1 TO EXPOSURE AREA 6

TOTAL DECONTAMINATION COSTS ARE . . . . . . . .

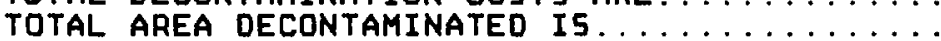

AREA REQUIRING NO DECONTAMINATION IS .......

AREA THAT COULD NOT BE DECONTAMINATED İ $\ldots \ldots$

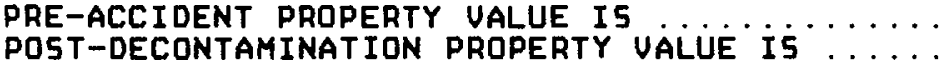

TOTAL REDUCTION IN PROPERTY VALUE IS ......

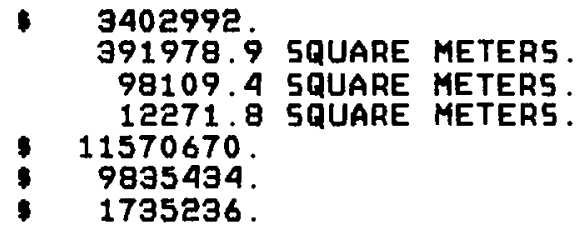

(b) TOTAL FACTOR INPUT REQUIREMENTS (MAN/EQUIPMENT HOURS)

COMMON LABOR

OPERATOR

CRAFTS WORKER

SPECIAL LABOR

LIQUID SPREADER TRUCK

HAND UACUUM

WET UACUUM

VACUUMIZED STREET SWEEPER

DUMP TRUCK

TRACTOR

BACK HOE

GRADER

FRONT END LOADER

HYDROBLAST EQUIPMENT

5ANDBLA5T EQUIPMENT

5PRAY EQUIPHENT

AIR COMPRE55OR AND TOOL5

CHIPPING MACHINE

PAUING MACHINE

A5PHALT PLANT

ROLLER

AIRPLANE

FLODR SANDING EQUIPMENT

CEMENT GRINDING EQUIPMENT

GAS CEMENT FINISH MACHINE

TANK TRUCK
38811.44

32686.80

20096.71

5.92

38.90

1514.68

2624.80

2. 55

2:2346.72

205.95

2e. 58

392.00

617.35

62.35

803.35

680.86

18.53

136.15

20.81

20.81

48.39

3. 33

143.14

1550.29

1760.50

5.13 
TMBLE 8. (Contin:led)

(c) TOTAL AREA DECONTAMINATED, gy SURFACE AND METHOD

SURFACE TYPE

METHOD

AREA (5Q. METERS)

AGRICULTURAL FIELDS AGRICULTURAL FIELDS

ORCHARD 5

ORCHARD 5

VACANT LAND

VACANT LAND

VACANT LAND

VACANT LAND

WOODED LAND

WOODED LAND

EXTERIOR WOOD WALL5

EXTERIOR WOOD WALLS

EXTERIOR WOOD WALLS

EXTERIOR WOOD WALL5

EXTER'R BRICK WALLS

EXTER'R BRICK WALLS

LINOLEUM FLOORS

LINOLEUM FLOORS

LINOLEUM FLOORS

LINOLEUM FLOORS

WOOD FLOORS

WOOD FLOORS

WOOD FLOORS

WOOD FLOORS

WOOD FLOORS

CARPETED FLOORS

CARPETED FLOORS

CARPETED FLOORS

CONCRETE FLOORS

CONCRETE FLOORS

CONCRETE FLOORS

CONCRETE FLOORS

INT'R WOOD/PL WALLS

INT'R WOOD/PL WALLS

INT'R WOOD/PL WALLS

INT'R WOOD/PL WALLS

INT'R CNCRETE WALLS

INT'R CNCRETE WALLS

INT'R CNCRETE WALLS

INT'R CNCRETE WALLS

A5PHALT STRT5/ROADS

A5PHALT STRTS/ROADS

CNCRETE STRTS/ROADS

CNCRETE STRTS/ROADS

ROOF 5

ROOF5

ROOF 5

LAWNS

LAWNS

LAWNS

LAWNS

OTHR PAUED ASPHALT

DTHR PAUED ASPHALT

OTHR PAUED CNCRETE

OTHR PAVED CNCRETE

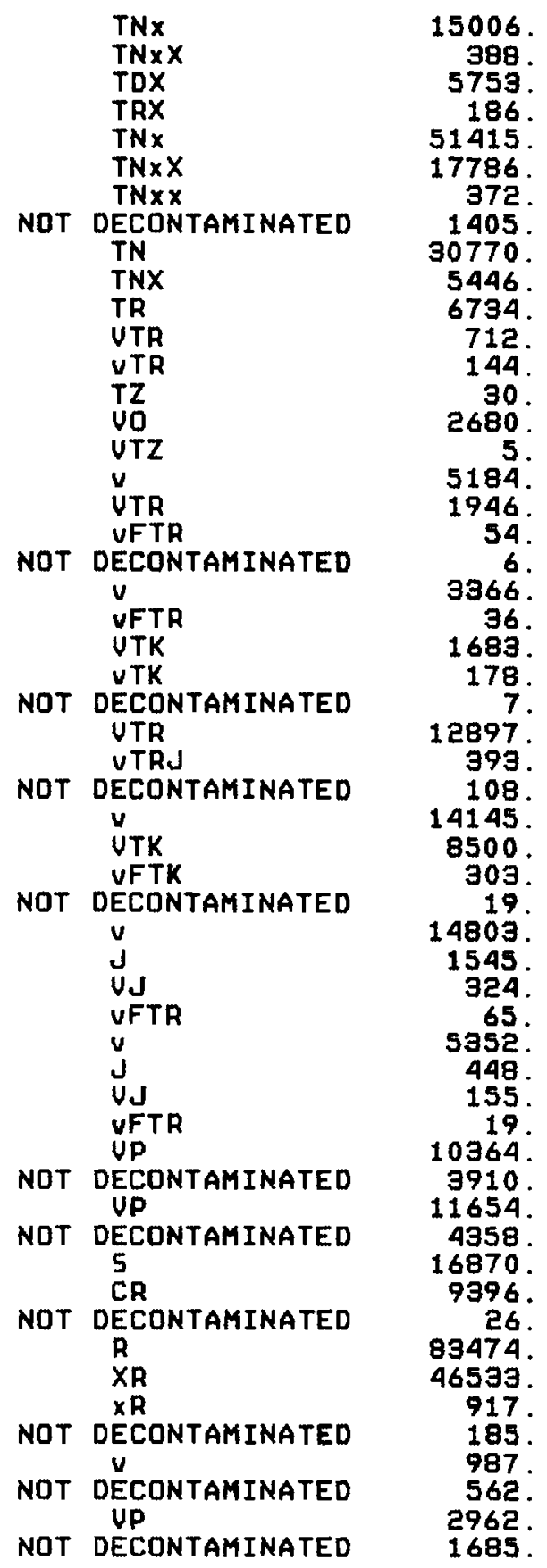




$\begin{array}{lrlr}\text { Agricultural Fields } & 1.0 & \text { Streets/Roads, Asphalt } & 6.0 \\ \text { Orchards } & 4.0 & \text { Streets/Roads, Concrete } & 6.0 \\ \text { Vacant Land } & 10.0 & \text { Wooded Land } & 10.0 \\ \text { Exterior Walls, Wood } & 1.5 & \text { Exterior Walls, Brick } & 1.5 \\ \text { Floors, Linoluem } & 0.5 & \text { Floors, Wood } & 0.5 \\ \text { Floors, Carpeted } & 0.5 & \text { Floors, Concrete } & 1.5 \\ \text { Interior Walls, Painted } & 0.5 & \text { Interior Walls, Concrete } & 1.5 \\ \text { Roofs } & 1.0 & \text { Lawns } & 1.3 \\ \text { Vehicle Transport } & 10.0 & \text { Auto Exteriors } & 2.0 \\ \text { Auto Interiors } & 0.9 & \text { Auto Tires } & 5.0 \\ \text { Auto Engine/Drive Train } & 1.6 & \text { Other Paved Surfaces/Asphalt } 1.0\end{array}$

The results of this analysis are sumarized in Table 9 panel (a). Total decontamination costs are a little over half of those in the base case: just $\$ 1.14$ million. More than 180,000 square meters of surface--nearly twice the area of the base case--require no decontamination at all. Finally, only 3,300 square meters could not be decontaminated, versus 12,300 in the base case. Based on this very preliminary result, varying the cleanup criteria according to expected exposure rate has the potential to provide significant cost savings without creating any additional health risk. However, if this option were to be exercised in practice, it would be important to take precautions to ensure that no one would receive high doses from surfaces with large exposure factors (i.e., rated for low exposures).

\subsubsection{The Trade-0ff Between Cleanup Standards and Decontamination Costs}

In this example DECON is used to demonstrate how one can establish the trade-off relationship between cleanup standards and decontamination costs. In the examples up to this point, radiation limits of 1.0 millirad and 3.0 millirads per year have been in effect for the luing and bone, respectively. We now consider corresponding radiation limits of 0.1 and 0.3 millirads; 0.3 and 0.9 millirads; 0.7 and 2.1 millirads; 3.0 and 9.0 millirads; 6.0 and 18.0 millirads; and 12.0 and 36.0 millirads. The results are presented in Table 10. The surface area that could not be decontaminated using methods currently in DECON should be especially noted. Over 65,000 square meters could not be decontaminated with a $(0.1,0.3)$ standard, compared with 12,271 with a $(1.0,3.0)$ standard and just 95 square meters with a $(12.0,36.0)$ standard. Methods adequate for decontaminating these surfaces will be costly, especially in those cases where the cleanup standards are very strict. 
TABLE 9. (Continued)

(c) TOTAL AREA DECONTAMINATED, BY SURFACE AND METHOD

SURFACE TYPE

AGRICULTURAL FIELDS

AGRICULTURAL FIELDS

ORCHARDS

ORCHARD 5

VACANT LAND

VACANT LAND

VACANT LAND

VACANT LAND

WOODED LAND

EXTERIOR WOOD WALLS

EXTERIOR WOOD WALL5

EXTERIOR WOOD WALLS

EXTER'R BRICK WALLS

EXTER'R BRICK WALLS

EXTER'R BRICK WALLS

EXTER'R BRICK WALL5

LINOLEUM FLOORS

LINOLEUM FLOORS

LINOLEUM FLOORS

LINOLEUM FLOORS

WOOD FLOORS

WOOD FLOORS

WOOD FLOORS

WOOD FLOORS

CARPETED FLOORS

CARPETED FLOORS

CARPETED FLOORS

CONCRETE FLOORS

CONCRETE FLOORS

CONCRETE FLOORS

CONCRETE FLOORS

CONCRETE FLOORS

INT'R WOOD/PL WALLS

INT'R WOOD/PL WALLS

INT'R WODD/PL WALLS

INT'R WOOD/PL WALLS

INT'R CNCRETE WALLS

INT'R CNCRETE WALLS

INT'R CNCRETE WALLS

ASPHALT STRTS/ROADS

ASPHALT STRTS/ROADS

ASPHALT. STRTS/ROADS

ASPHALT 5TRT5/ROADS

CNCRETE STRTS/ROADS

CNCRETE STRTS/ROADS

CNCRETE STRTS/ROADS

CNCRETE STRTS/ROADS

ROOF 5

ROOF 5

ROOF 5

LAWNS

LAWNS

LAWN5

LAWNS

DTHR PAUED ASPHALT

OTHR PAUED ASPHALT

OTHR PAVED CNCRETE

OTHR PAUED CNCRETE
METHOD AREA (5Q. METERS)

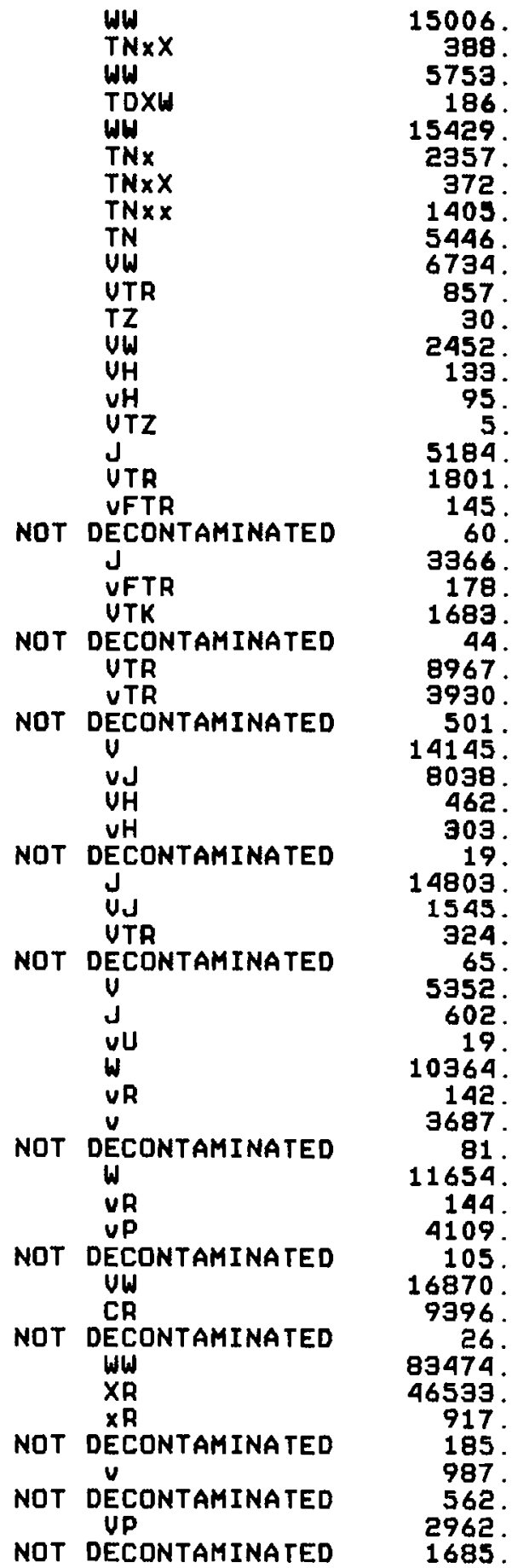


TABLE 10. Trade-Off Between Radiation Standards and Decontamination Costs

\begin{tabular}{crrrr}
$\begin{array}{c}\text { Radiation } \\
\text { Standard } \\
\text { (mR to Lung) }\end{array}$ & $\begin{array}{c}\text { Total Cost to } \\
\text { Decontaminate }\end{array}$ & $\begin{array}{c}\text { Cost Per } \\
\text { Square Meter }\end{array}$ & $\begin{array}{c}\text { Area Not Decontaminated } \\
\text { Unable to } \\
\text { Unnecessary to }\end{array}$ \\
\hline 0.1 & $\$ 5,067,269$ & $\$ 11.78$ & $65,735.6$ & $6,532.4$ \\
0.3 & $4,075,001$ & 8.56 & $19,760.4$ & $6,532.4$ \\
0.7 & $3,444,947$ & 7.92 & $12,747.8$ & $54,642.0$ \\
1.0 & $2,119,086$ & 5.41 & $12,271.8$ & $98,109.4$ \\
3.0 & 967,310 & 2.40 & 781.4 & $98,109.4$ \\
6.0 & 675,889 & 1.92 & 285.6 & $149,926.3$ \\
12.0 & 297,296 & 2.61 & 95.0 & $388,367.9$
\end{tabular}

\subsection{CYPRESS PARK: BASE CASE}

DECON can be used to analyze virtually any subarea with in an accident site. To demonstrate this capability we have applied DECON to the irregular area that defines the residential development Cypress Park (see Figure 1). Except for the area involved, the other relevant parameters are the same as in the NUWAX base case. The results are summarized in Table 11, panel (a). Total decontamination costs are $\$ 323,469$ with 77,543 square meters decontaminated, for an average per square meter cost of $\$ 4.17$. In addition, approximately 19 percent--or about $\$ 700,000$--of the original property value of $\$ 370$ thousand was lost because of residual contamination. Nearly 2,500 square meters of asphalt and concrete surfaces could not be decontaminated.

\subsection{CYPRESS PARK: BAN ON WATER OPERATIONS}

In this example it is hypothesized that the residents of Cypress Park are apprehensive about allowing the contaminants to penetrate into the soil. An analysis is required to determine the additional decontamination costs if methods using water are to be rejected. The results with water methods prohibited are reported in Table 12. Total decontamination costs increase substantially to $\$ 567,126$, for an average per square meter cost of $\$ 7.31$. Vacant land is now fixed, cleared and scraped; roofs are sandblasted; and lawns are resodded.

\subsection{INDUSTRIAL PARK: BASE CASE}

DECON can also provide an analysis where a particular decontamination method is specified. For example, the contamination may have occurred in a foreign country where only minimal equipment or materials are available for the 
TABLE 11. Decontamination Results for Cypress Park:

Base Case

\begin{abstract}
(a) SUMMARY RESULT5 FOR EXPOSURE AREA 63 TO EXPO5URE AREA 416
TOTAL DECONTAMINATION COSTS ARE...........

TOTAL AREA DECONTAMINATED IS.

AREA REQUIRING NO DECONTAMINATION İ $\cdots \cdots \cdots$

AREA THAT COULD NOT BE DECONTAMINATED I $5 \ldots \ldots$

PRE-ACCIDENT PROPERTY UALUE IS ...........

POST-DECONTAMINATION PROPERTY UALUE IS ......

TOTAL REDUCTION IN PROPERTY UALUE IS $\ldots \ldots$

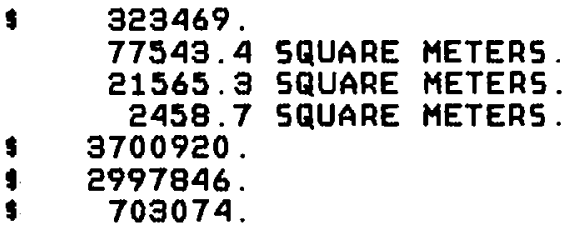

\section{(b) TOTAL FACTOR INPUT REQUIREMENTS} (MAN/EQUIPMENT HOURS)

COMMON LABOR

OPERATOR

CRAFTS WORKER

SPECIAL LABOR

LIQUID SPREADER TRUCK

HAND VACUUM

WET UACUUM

UACUUMIZED STREET SWEEPER

DUMP TRUCK

TRACTOR

GRADER

FRONT END LOADER

HYDROBLAST EQUIPMENT

SPRAY EQUIPMENT

NONMOBILE PUMP (HI-PRESSURE WATER)

CHIPPING MACHINE

PAUING MACHINE

ASPHALT PLANT

ROLLER

AIRPLANE

FLOOR SANDING EQUIPMENT

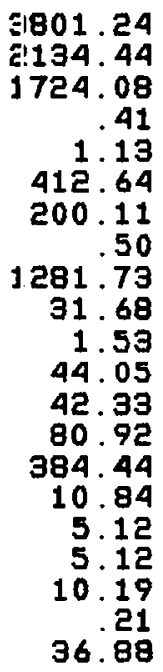


TABLE 11. (Continued)

(c) TOTAL AREA DECONTAMINATED, BY SURFACE AND METHOD

SURFACE TYPE

VACANT LAND

VACANT LAND

WODDED LAND

HOODED LAND

EXTERIOR WOOD WALLLS

EXTERIOR WOOD WALLS

EXTER'R BRICK WALLS

LINOLEUM FLOORS

LINOLEUM FLOORS

WOOD FLOOR5

WOOD FLOORS

WOOD FLOORS

CARPETED FLOORS

CARPETED FLOORS

CONCRETE FLOORS

CONCRETE FLOOR5

INT'R WOOD/PL WALL5

INT'R WOOD/PL WALLS

INT'R CNCRETE WALLS

INT'R CNCRETE WALLS

A5PHALT 5TRTS/ROADS

A5PHALT 5TAT5/ROADS

CNCRETE STRT5/ROADS

CNCRETE STRT5/ROADS

RODF 5

RDOF 5

LAWN5

LAWN5

DTHA PAUED ASPHALT

OTHR PAUED ASPHALT

OTHR PAVED CNCRETE

OTHR PAUED CNCRETE
METHOD AREA (5Q. METER5)

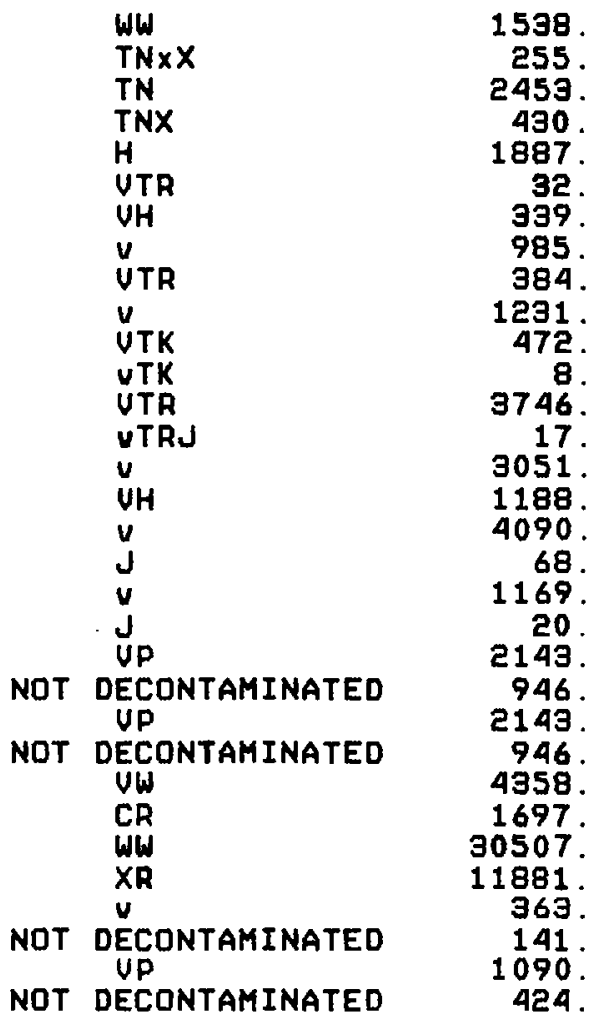


TABLE 12. Decontamination Results for Cypress Park:

Ban on Water Operations

(a) SUMMARY RESULTS FOR EXPOSURE AREA 6I TO EXPOSURE AREA 416

TOTAL DECONTAMINATION COSTS ARE..........

TOTAL AREA DECONTAMINATED IS.

AREA REQUIRING NO DECONTAMINATION IS

AREA THAT COULD NOT BE DECONTAMINATED I $5 \ldots .$.

PRE-ACCIDENT PROPERTY UALUE IS ..........

POST-DECONTAMINATION PROPERTY UALUE IS .....

TOTAL REDUCTION IN PROPERTY UALUE IS $\cdots \cdots$

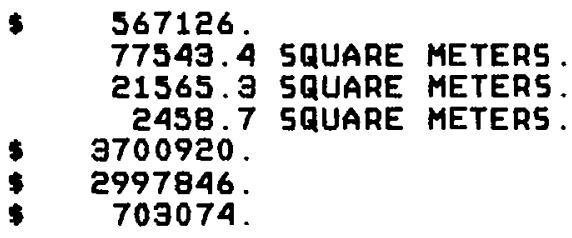

(b) TOTAL FACTOR INPUT REQUIREMENTS (MAN/EQUIPMENT HOURS)

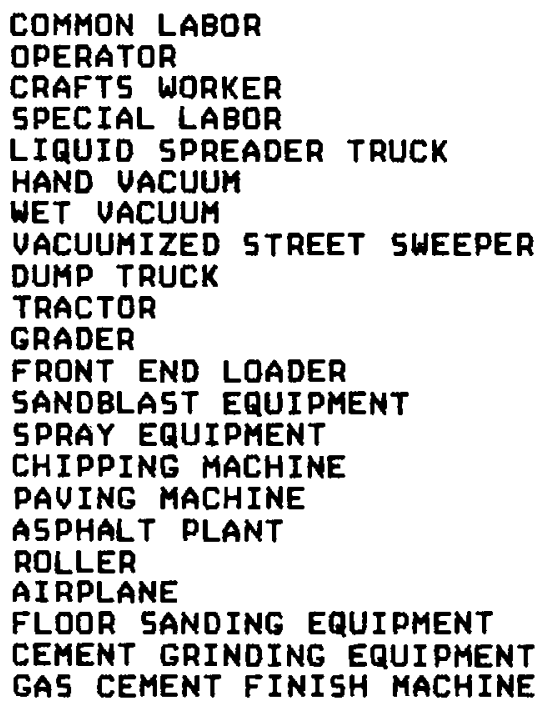

8951.85
3415.34
4792.72
.41
.72
358.84
420.26
.50
1423.19
31.68
7.68
50.20
207.53
150.07
10.84
5.12
5.12
10.19
.21
36.88
203.47
237.63 
TABLE 12. (Continued)

(c) TOTAL AREA DECONTAMINATED, BY SURFACE AND METHOD

SURFACE TYPE

UACANT LAND

UACANT LAND

WOODED LAND

WOODED LAND

EXTERIOR WOOD WALLS

EXTERIOR WOOD WALLS

EXTER'R BRICK WALLS

LINOLEUM FLOORS

LINOLEUM FLOORS

WOOD FLOORS

WOOD FLOORS

WOOD FLOORS

CARPETED FLOORS

CARPETED FLOORS

CONCRETE FLOORS

CONCRETE FLOORS

INT'R WOOD/PL WALL5

INT'R WOOD/PL WALL5

INT'R CNCRETE WALLS

INT'R CNCRETE WALLS

A5PHALT 5TRT5/ROADS

ASPHALT STRTS/ROADS

CNCRETE STRTS/ROAD5

CNCRETE STRTS/ROADS

ROOF5

ROOF 5

LAWNS

LAWNS

OTHR PAUED A5PHALT

OTHR PAVED A5PHALT

DTHR PAUED CNCRETE

OTHR PAUED CNCRETE
METHOD

AREA (5Q. METERS)

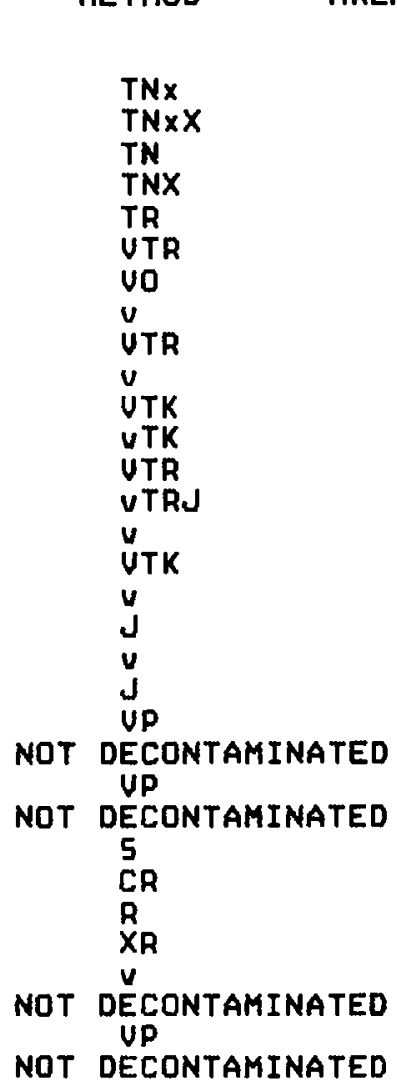

1538 .

255.

2453.

430 .

1887 .

32 .

339 .

985 .

384.

1231 .

472 .

3746

17 .

3051 .

1188 .

4090 .

68 .

1169.

20 .

2143

946 .

2143.

946.

4358 .

1697

30507 .

11881 .

363.

141.

1090.

424. 
cleanup. Alternatively, a method may be preferred if it is not significantly more costly than the method selected by DECON. With this feature of DECON, the alternative method can be checked out to evaluate more fully its relative merits. To illustrate this technique, we first run a base case for the Port Gaston Industrial Park. The results are reported in Table 13. Nearly 25,000 square meters of surfaces are decontaminated at a total cost of about $\$ 150,000$, or about $\$ 6$ per square meter. It was unnecessary to decontaminate another 25,000 square meters of surfaces, while 1,350 square meters of surfaces could not be decontaminated with methods currently in DECON. Prior to the accident, property within the industrial park had a market value of $\$ 3.25$ million. After decontamination has been completed, property losses will amount to $\$ 193$ thousand.

\subsection{INDUSTRIAL PARK: PRE-SPECIFIED DECONTAMINATION METHODS}

To illustrate the use of pre-specified decontamination methods, we will require that the following methods be used within the Port Gaston Industrial Park: exterior brick walls - vacuum and scarify; vacant land - fix, clear and scrape as necessary; asphalt and concrete roads - add a thin layer of asphalt; roofs - fix with strippable coating and replace; lawns - scrape as necessary and resod. The results with these restrictions are presented in Table 14.

These restrictions cause decontamination costs to increase from $\$ 148$ thousand to $\$ 272$ thousand. The latter figure includes decontamination of 448 square meters of asphalt streets/roads and 895 square meters of concrete streets/roads that were not decontaminated without the restrictions. It is noted that the required method is adopted regardless of whether or not it satisfies the cleanup criteria. In the case of these streets and roads, adding a thin layer of asphalt to the surface will not decontaminate these surfaces to the prespecified cleanup standard.

\subsection{MICRO-ANALYSIS OF THE ACCIDENT SITE}

The features of DECON discussed so far are well-suited to planning an overall decontamination strategy. However, for detailed decontamination planning and analysis, one would like to have specific information about each grid element within the contaminated area. DECON has the ability to provide this information, including the quantity of each surface type within the grid element and the most cost-effective decontamination method to use on that 
TABLE 13. Decontamination Results for Port Gaston

Industrial Park: Base Case

(a) SUMMARY RESULTS FOR EXPOSURE AREA 963 TO EXPOSURE AREA 1181

TOTAL DECONTAMINATION COSTS ARE

TOTAL AREA DECONTAMINATED IS.

AREA REQUIRING NO DECONTAMINATION I $5 \ldots \ldots \ldots$ AREA THAT COULD NOT BE DECONTAMINATED I $5 \ldots \ldots$

PRE-ACCIDENT PROPERTY VALUE IS ..........

POST-DECONTAMINATION PROPERTY VALUE I $5 \ldots \ldots$

TOTAL REDUCTION IN PROPERTY VALUE I5 .......

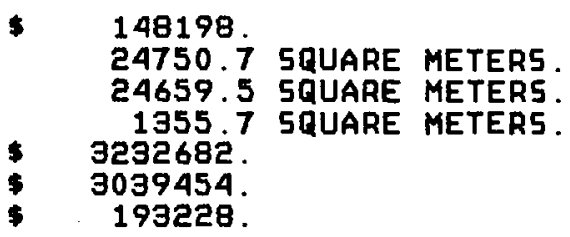

(b) TOTAL FACTOR INPUT REQUIREMENTS (MAN/EQUIPMENT HOURS)

$$
\begin{array}{r}
2604.32 \\
768.22 \\
853.04 \\
1.18 \\
266.69 \\
697.80 \\
.23 \\
202.27 \\
1.25 \\
8.03 \\
9.28 \\
158.78 \\
54.27 \\
485.86 \\
1.51 \\
1.51 \\
4.54 \\
38.74 \\
42.64
\end{array}
$$

(c) TOTAL AREA DECDNTAMINATED, BY 5URFACE AND METHOD

SURFACE TYPE

UACANT LAND

VACANT LAND

EXTER'R BRICK WALL5

EXTER'R BRICK WALLS

LINOLEUM FLOORS

LINOLEUM FLOORS

LINOLEUM FLOORS

CARPETED FLOORS

CARPETED FLOORS

CARPETED FLOORS

CONCRETE FLOORS

CONCRETE FLOORS

CONCRETE FLOORS

INT'R WOOD/PL WALLS

INT'R WOOD/PL WALLS

INT'R WOOD/PL WALLS

INT'R CNCRETE WALLS

INT'R CNCRETE WALLS

INT'R CNCRETE WALLS

A5PHALT 5TRTS/ROADS

A5PHALT STRTS/ROADS

CNCRETE STRTS/ROADS

CNCRETE STRTS/RDADS

ROOF 5

RODF 5

LAWN5

LAWN5

LAWN5
METHOD

AREA (5Q. METER5)

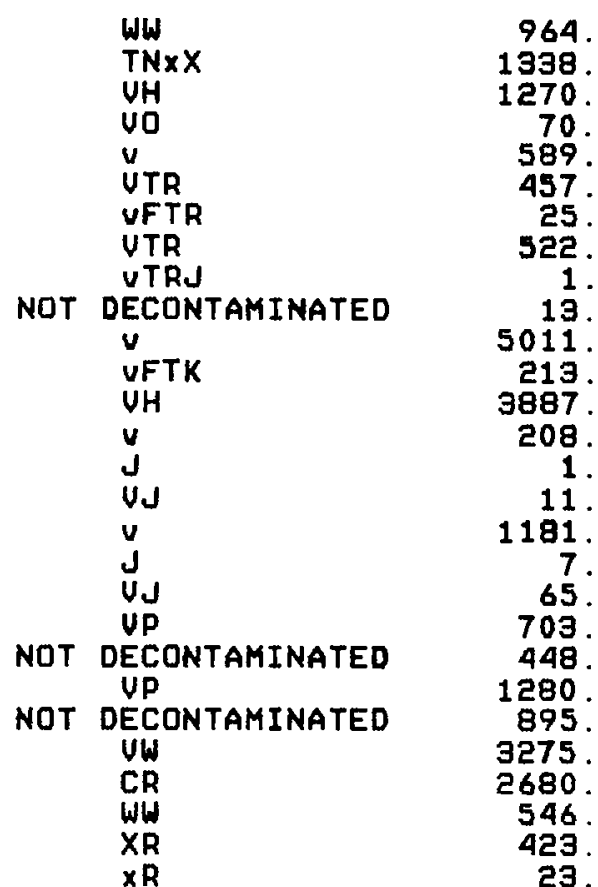


FIGURE 14. Decontamination Results for Port Gaston Industrial Park: Pre-Specified Decontamination llethods

\section{(a) SUMMARY RESULTS FOR EXPOSURE AREA 963 TO E:XPOSURE AREA 1181}

TOTAL DECONTAMINATION COSTS ARE . . . . . . . .

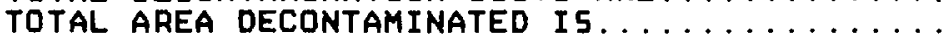

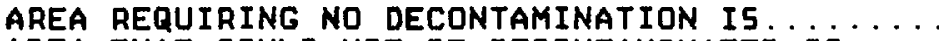

AREA THAT COULD NOT BE DECONTAMINATED I5 ....

PRE-ACCIDENT PROPERTY VALUE IS $\ldots \ldots \ldots$

POST-DECONTAMINATION PROPERTY VALUE IS .....

TOTAL REDUCTION IN PROPERTY VALUE IS $\ldots \ldots \ldots$

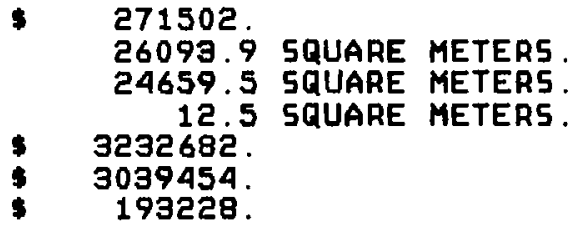

(b) TOTAL FACTOR INPUT REQUIREMENTS (MAN/EQUIPMENT HOURS)

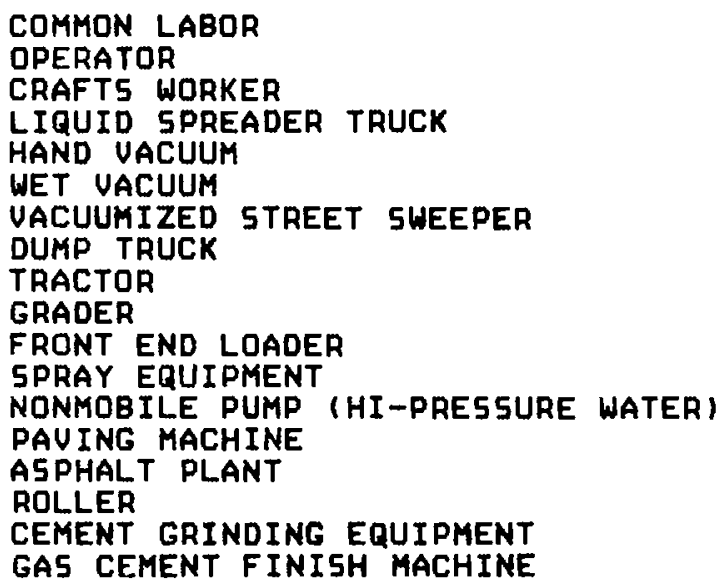

4487.83
425.43
1482.82
.92
226.26
856.58
.39
301.54
1.25
11.88
13.14
94.20
485.86
2.57
2.57
7.72
356.30
42.64

(c) TOTAL AREA DECONTAMINATED, BY SURFACE AND METHOD

SURFACE TYPE

UACANT LAND

VACANT LAND

EXTER'R BRICK WALLS

LINOLEUM FLOORS

LINOLEUM FLOORS

LINOLEUM FLOORS

CARPETED FLOORS

CARPETED FLOORS

CARPETED FLOORS

CONCRETE FLOORS

CONCRETE FLOORS

CONCRETE FLOORS

INT'R WOOD/PL WALL5

INT'R WOOD/PL WALLS

INT'R WOOD/PL WALLS

INT'R CNCRETE WALLS

INT'R CNCRETE WALLS

INT'R CNCRETE WALLS

ASPHALT STRTS/ROADS

CNCRETE STRTS/ROADS

ROOF 5

LAWNS

LAWN5

LAWN5
METHOD

AREA (5Q. METERS)
964.
1338.
1340.
589.
457.
25.
522.
1.
13.
5011.
213.
3887.
208.
1.
11.
1181.
7.
65.
1150.
2175.
5955.
546.
423.
23. 
surface. Other useful information is provided as well. A complete output for a single grid element is presented in Table 15. The grid element selected is with in the residential development of Hillview.

One piece of information in Table 15 requires some additional explanation. In panel (d) there is an item labeled "Total Potential Savings from Property Buy-Out: 1) at Pre-Accident Property Values, and at 2) Post-Decontamination Property Values." If the cost to decontaminate an entire grid element exceeds either the pre-accident or post-decontamination value of the property within that grid element, then the difference between the decontamination cost and the pre-accident/post-decontamination cost is presented. This is the potential savings from compensating the property owner for his losses and then condemning the property (rather than decontaminating it).

Panel (d) at the end of Table 15 repeats information presented in panel (b). However, if a detailed analyis is requested on a group of grid elements, say those within the industrial park, then panels (d) through (e) will summarize the information for all of the grid elements while panels (a) through (c) will provide information on each of the grid elements. Thus, where a group of grid elements is analyzed, the various panels do not duplicate the information presented.

Restrictions on the use of particular methods, the Quick-Vac option and the other special features of DECON noted earlier can also be applied with respect to the micro-analysis. Thus, very detailed strategies can be analyzed and incorporated into the overall decontamination $\mathrm{plan}$. 
TABLE 15. Micro-Analys is of a Single Grid Element

(a) SUMMARY RESULTS FOR GRID ELEMENT 778

*** RAIN ***

PROB, OF RAIN/SNOW BEFORE DECONTAMINATING... 1.0000.

\begin{tabular}{|c|c|c|c|c|c|c|c|c|}
\hline $\begin{array}{l}\text { SURFACE } \\
\text { EXTERIOR WOOD WALLS } \\
\text { EXTER'R BRICK WALLS } \\
\text { LINOLEUM FLOORS } \\
\text { WOOD FLOORS } \\
\text { CARPETED FLOORS } \\
\text { CONCRETE FLOORS } \\
\text { INT'R WOOD /PL WALLS } \\
\text { INT'R CNCRETE WALLS } \\
\text { ROOFS } \\
\text { LAWN5 } \\
\text { OTHR PAUED ASPHALT } \\
\text { OTHR PAUED CNCRETE }\end{array}$ & $\begin{array}{r}\text { AREA } \\
31 \\
5 \\
6 \\
7 \\
17 \\
19 \\
68 \\
19 \\
27 \\
195 \\
2\end{array}$ & $\begin{array}{r}\text { DOSE } \\
5.50 \\
5.50 \\
27.50 \\
27.50 \\
27.50 \\
27.50 \\
2.75 \\
2.75 \\
55.00 \\
55.00 \\
55.00\end{array}$ & $\begin{array}{r}\text { ATDF } \\
5.5 \\
5.5 \\
27.5 \\
27.5 \\
27.5 \\
27.5 \\
2 . B \\
2.8 \\
55.0 \\
55.0 \\
55.0\end{array}$ & $\begin{array}{l}\text { METH } \\
W \\
W \\
v J \\
v J \\
\text { UTR } \\
v J \\
v \\
u \\
\text { CR } \\
\times R \\
I I I I \\
I I I I\end{array}$ & $\begin{array}{r}D F \\
6.7 \\
6.7 \\
33.3 \\
33.3 \\
50.0 \\
33.3 \\
4.0 \\
4.0 \\
1999.9 \\
393.3 \\
* * * * * * * * \\
* * * * * * * *\end{array}$ & $\begin{array}{r}\text { COST/M**2 } \\
.0095 \\
.0095 \\
1.1000 \\
1.1000 \\
24.6800 \\
1.1000 \\
.2700 \\
.2700 \\
21.8800 \\
5.0100 \\
* * * * * * * * * \\
* * * * * * * * *\end{array}$ & $\begin{array}{r}\text { TOT. C05T } \\
.30 \\
.05 \\
6.93 \\
8.66 \\
427.50 \\
21.46 \\
18.44 \\
5.27 \\
609.82 \\
977.44 \\
k * * * * * * * * * \\
* * * * * * * * * *\end{array}$ & $\begin{array}{r}\text { RATE } \\
2200 \\
2200 \\
36\end{array}$ \\
\hline
\end{tabular}

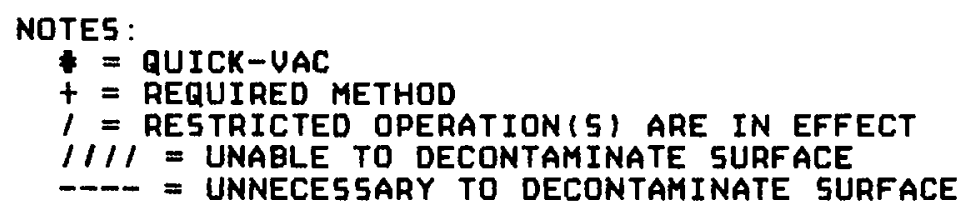

(b) SUMMARY RESULTS FOR GRID ELEMENT 778:

TOTAL SURFACE AREA DECONTAMINATED

TOTAL SURFACE AREA NOT DECONTAMINATED

TOTAL COST OF DECONTAMINATING THIS GRID ELEMENT

PRE-ACCIDENT PROPERTY UALUE OF THIS GRID ELEKENT $\ldots \ldots \ldots$

POST-DECONTAMINATION PROPERTY UALUE OF THIS GRID EL.EMENT \$

(c) FACTOR INPUT REQUIREMENTS (MAN/ EQUIPMENT HOURS)

COMMON LABOR

OPERATOR

CRAFT5 WORKER

HAND UACUUM

WET VACUUM

DUMP TRUCK

TRACTOR

FRONT END LOADER

SPRAY EQUIPMENT

$$
\begin{array}{r}
28.31 \\
8.58 \\
11.13 \\
2.12 \\
.94 \\
1.04 \\
.52 \\
.52 \\
.56
\end{array}
$$

398.8 5Q. METERS

9.3 5Q. METERS 1.0000 . 2076 . 10453

8362 . 
TABLE 15. (Continued)

(d) SUMMARY RESULTS FOR GRID ELEMENT 778 TO GRID ELEMENT 778

TOTAL DECONTAMINATION COSTS ARE..........

TOTAL AREA DECONTAMINATED IS.

AREA REQUIRING NO DECONTAMINATION I5

AREA THAT COULD NOT BE DECONTAMINATED I5 .....

PRE-ACCIDENT PROPERTY VALUE IS ..........

POST-DECONTAMINATION PROPERTY UALUE IS .....

TOTAL REDUCTION IN PROPERTY UALUE IS $\ldots \ldots$

TOTAL POTENTIAL 5AUINGS FROM PROPERTY BUY-OUT

1) AT PRE-ACCIDENT PROPERTY UALUES . . .

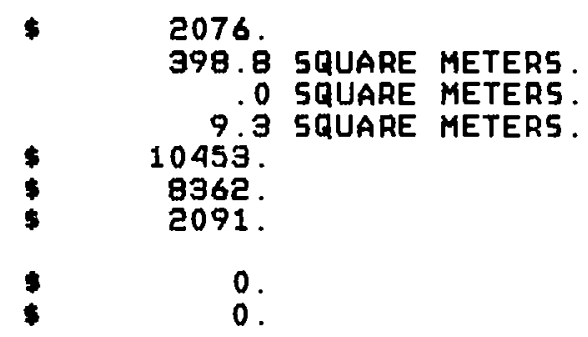

(e) TOTAL FACTOR INPUT REQUIREMENTS (MAN/EQUIPMENT HOURS)

COMMON LABOR
OPERATOR
CRAFTS WORKER
HAND UACUUM
WET UACUUM
DUMP TRUCK
TRACTOR
FRONT END LOADER
SPRAY EQUIPMENT

28.31

8.58

11. 13

2. 12

.94

1.04

.52

.52

SPRAY EQUIPMENT

(\$) TOTAL AREA DECONTAMINATED, BY SURFACE AND METHOD

SURFACE TYPE

METHOD

AREA (5Q. METERS)

EXTERIOR WOOD WALLS

EXTER'R BRICK WALLS

LINOLEUM FLOORS

WOOD FLOORS

CARPETED FLOORS

CONCRETE FLOORS

INT'R WOOD/PL WALLS

INT'R CNCAETE WALLS

ROOFS

LAWNS

OTHR PAUED ASPHALT

OTHA PAVED CNCRETE

$w$
$w$
$v J$
$v J$
$u T R$
$v J$
$u$
$u$
$C R$
XR
NOT DECONTAMINATED
NOT DECONTAMINATED

32 .

6.

6.

17 .

20 .

68

20 .

28.

195.

NOT DECONTAMINATED 


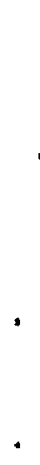

•

- 


\section{$\underline{\text { DISTRIBUTION }}$}

No. of

Copies

\section{OFFSITE}

60 LCmdr. Cart Fesler FCDNA/Capabilities Division Defense Nuclear Agency Kirtland Air Force Base New Mexico 87115

John M. Taylor Sandia Nationa 1 Laboratory Organization 6231

Albuquerque, NM 87185

Capt. Robert H. Wank Office of Military Applications DP 226

Washington, D.C. 20545

Bernie Wise

Instant Response and Development Branch U.S. Nuclear Regulatory Commission Washington, D.C. 20555

Joe Logsdon

Office of Radiation Programs

Guides \& Criteria Branch (ANR-460) U.S. Environmental Protection Agency Washington, D.C. 20560

27 DOE Technical Information Center

\section{ONSITE}

DOE - Richland Operations

H.E. Ransom

31 Pacific Northwest Laboratory Publishing Coordination (2) Technical Information Files(5) Jack Tawi1 (24) 
.

, 